\title{
Growing Chlorella vulgaris into bioreactors set in solar greenhouse, towards biofuel: Nutrient composition
}

\begin{abstract}
In the current research, the macro- and micro-nutrient profile of Chlorella vulgaris microalgae, grown in bioreactors set in solar greenhouse, is reported. Actually, unicellular algae species present new opportunities for producing a variety of sustainable and eco-friendly products, as they possess several advantages when compared to conventional crops, such as faster grow rates, cultivation in open or closed bioreactors without the use of energy consuming and environment polluting pesticides and insecticides. Of great importance is their macro- and micro-nutrient content that constitutes another opportunity for harvesting and exploiting algae as an additive to animal feeds and supplement to human nutrition. Typical nutrient composition of the dry algal biomass of a sample grown in typical growth media and bioreactor conditions is lipids $24-33 \%$, proteins $31-36 \%$, starch $4.2-4.6 \%$, total fiber $10-11.4 \%$ and ash $8.7-12.2 \%$. For the three macronutrients, the lipid content can vary from $8 \%$ to $42 \%$, while the protein content is found to vary between $34 \%$ and $40 \%$. The total carbohydrate content varies between $7 \%$ and $20 \%$. The content of Chlorella vulgaris biomass in antioxidant micronutrients also appears to be significant, offering a high antioxidant capacity, about $50 \%$ higher than that of red wine.
\end{abstract}

Volume 5 Issue 2 - 2018

\author{
Papapolymerou G,I Karayannis V,2 \\ Gougoulias N,3 Kantas D,3 Papadopoulos \\ S,3 Spiliotis XI \\ 'School of Technological Applications, University of Applied \\ Sciences of Thessaly, Greece \\ ${ }^{2}$ School of Technological Applications, Western Macedonia \\ University of Applied Sciences, Greece \\ ${ }^{3}$ School of Agricultural Technology, University of Applied \\ Sciences of Thessaly, Greece
}
Correspondence: Karayannis V, School of Technological Applications, Western Macedonia University of Applied Sciences, Kozani, Greece,
Email vkarayan@teiwm.gr, vkarayan62@gmail.com

Received: December 0I, 2017 | Published: March 30, 2018

Keywords: Chlorella vulgaris, microalgae, macro/micro nutrient, composition, bioreactor, solar greenhouse, biofuel, FRAP

\section{Introduction}

In the current work, the macronutrient content of microalgae Chlorella vulgaris is reported in a standard growth media and also in media of varying concentration of nitrogen. Also the major fatty acids in the lipids extracted from the microalgal biomass are reported.

Large scale microalgae cultivation actually represents a potential new source of renewable energy in the form of biofuel. Microalgae are individual plant cells which have the ability to photosynthesize and therefore utilize $\mathrm{CO}_{2}$, micronutrients and solar light to multiply and produce carbohydrates, lipids and proteins. Microalgae cultivation has several advantages over land grown crops. The major advantages are 1) a much faster growth rate, 2) the fact that their cultivation does not need the application of insecticides and pesticides and 3 ) the potential for cultivation in large scale in either open ponds or closed photobioreactors. As microalgae cultivation removes atmospheric carbon dioxide their cultivation can be potentially scaled up in such a way as to absorb $\mathrm{CO}_{2}$ emissions from fossil fuel burning factories. Additionally, the spent algal mass, after the oil extraction, can be used either as an animal feed, since it contains substantial quantities of proteins, carbohydrates, some remaining oil and various micronutrients, or as an agricultural soil additive-nutrient enhancer. In recent years, several studies have been carried out both on a fundamental and on an applications oriented basis concerning the synergistic cultivation of microalgae for biofuel production with biological $\mathrm{CO}_{2}$ sequestration. ${ }^{1-5}$ This constitutes a priority for many governments, especially in places where conditions are favorable for cultivation of microalgae. Prices of oil, limited resources, and environmental pollution including greenhouse gas effect caused by fossil fuel burning are pressing for alternative and recycle fuel forms. Particularly, current research effort on biofuel production from algae mainly focuses on cultivating microalgae due to its less complex structure, fast growth rate, and high oil content. Several studies report that microalgae utilization as feedstock for biofuel production constitutes a great challenge nowadays and that it has a lot of advantages compared to conventional terrestrial crops. ${ }^{6-10}$ Besides, the great potential of microalgae to serve as solar-powered factories and reveal further considerable advantages compared to plant-based production systems is also demonstrated in other studies. ${ }^{11,12}$

Microalgae contain many macro and micronutrients suitable for human nutrition. ${ }^{13-15}$ Species from genus like Scenedesmus, Spirulina and Chlorella have been searched and used both for human and animal nutrition. Lately, the use of microalgae as additive in animal feed is becoming important due to the realization that the protein content of some algae species is up to $60 \%$ of its mass on a dry basis. ${ }^{16-18}$ Their carbohydrates are in the form of glucose, starch and other polysaccharides. As animal feed they can be incorporated into other feed (grains) in various proportions. The main applications are primarily in fisheries and poultry farms and secondarily in other farm animals. Their protein content is much higher than that of grains. Microalgae protein is also more balanced in the essential amino acids needed not only in animal nutrition but also in human nutrition. Amino acid distribution in the protein of some species of microalgae seems to be far superior when compared to grain protein. The lipids of many algae species also possess an important feature: they contain substantial quantities of $\omega-3$ fatty acids ( $\alpha$-linolenic acid), up to 35\% of their total lipid content, rendering them an important dietary factor for animal and human nutrition.

The most promising application as a nutritional supplement seems 
to be in fisheries followed by chicken farms. With respect to its use in fish farming it appears that its content in $\omega-3$ fatty acids is especially useful and it been found that certain algae strengthen the immune system of fish. ${ }^{19-22}$ In fish farms, certain species of algae can be fed directly as food after mixing with conventional feed (mostly grains) or indirectly as food to zooplankton which, can then be used as feed for fish. The most important zooplankton is copepods and various Artemisia species. Apart from an animal feed, algae also contain certain micronutrients which are very important as food supplements in human nutrition, most important of which seem to be astaxanthin and other carotenoids. ${ }^{14,15}$

Three other significant advantages in cultivating algae, besides those aforementioned, are 1) the immense number of species one can choose to suit a particular application, 2) the fact that their production can be put on an industrial scale and 3) that for a specific species of algae its macronutrient content can be altered during the course of cultivation by altering the process parameters. The last is especially useful in animal production. The protein and lipid content can be changed and this may be useful in chicken farm raising and perhaps in fisheries because, dietary needs during the poultry rising are different. Chicken early on require a diet rich in protein but in the later stages of farming they require a diet richer in lipids. Also, not only the percent lipid content can be changed by altering the process parameters but, also the fatty acid profile as well.

Various process parameters such as $\mathrm{CO}_{2}$, temperature and especially nutrient composition of the growth media affect lipid content in algal biomass. ${ }^{23-27}$ Nitrogen concentration in the cultivation process significantly affects both growth rate and oil content of the algal biomass. Actually, all available nitrogen is utilized for synthesis of essential enzymes and cellular structures and nitrogen starvation promotes lipid accumulation. Since the amount of $\mathrm{CO}_{2}$ being taken up by the cell remains the same, the carbon is mainly used to make carbohydrates or lipids rather than proteins. Some researchers proposed a two-stage cultivation strategy: in the first stage, nitrogen exists in abundance in order to increase biomass, and in the second conducted under conditions of nitrogen starvation, the lipid content increases significantly. The source of nitrogen is also very important, as it was found that nitrate concentration favors biomass productivity while ammonium concentration results in oil content enhancement On the other hand, under phosphorus shortage conditions, an increase in lipid production was observed, which is attributed to the breakdown of cell membrane of the phospholipids into neutral lipids in order to obtain phosphorus. In contrast, the addition instead of restriction of iron promotes the lipid production.

Both $\mathrm{pH}$ and $\mathrm{CO}_{2}$ supply also affect the macronutrient content The maintenance of an optimum $\mathrm{pH}$ range throughout culturing is very important as it influences all aspects of media biochemistry and especially growth rates. Both, ionic absorption from the media and the metabolic biochemistry of the cell, strongly affect $\mathrm{pH}$ level, and in high performance cultivations their effect is powerful enough to overcome the neutralizing capacity of exogenous buffering agents. Nowadays, microinjection of strong acids and alkalis, metabolic balancing in heterotrophic cultures and regulated $\mathrm{CO}_{2}$ dissolution in both photoautotrophic and heterotrophic cultures, are the most practical and economical strategies for $\mathrm{pH}$ control. $\mathrm{CO}_{2}$ absorption varies from day to night and this affects the $\mathrm{pH}$ of the growth media. Some microalgal species flocculate in response to $\mathrm{pH}$ shifts but, spontaneous flocculation is however unpredictable and unwanted as it removes biomass from the reactor. Accumulation of biomass on the surface of the bioreactor in open system is unwanted because in the absence of adequate stirring and bubbling of air it leads to an adequate dissolution of $\mathrm{CO}_{2}{ }^{\mathrm{i}} \mathrm{n}$ the growth media. Sufficient mixing in all photo-bioreactors ensures better $\mathrm{CO}_{2}$ supply and $\mathrm{CO}_{2}$ distribution and also prevents $\mathrm{O}_{2}$ accumulation and cell sedimentation.

\section{Materials and methods}

The microalgal species, Chlorella vulgaris, was obtained from the Experimental Psychology and Culture Collection of Algae at the University of Goettingen, Germany (EPSAG). It has been kept at $4^{\circ} \mathrm{C}$ and each vial was used within 3 months. The growth medium was of the following constitution suggested by Andersen et al. ${ }^{28}$ : Each 50 L growth medium contains: $0.2 \mathrm{~g} \mathrm{KNO}_{3} \mathrm{~L}^{-1}, 0.02 \mathrm{~g} \mathrm{~K}_{2} \mathrm{HPO}_{4} \mathrm{~L}^{-1}, 0.02$ g $\mathrm{MgSO}_{4} 7 \mathrm{H}_{2} \mathrm{O} \cdot \mathrm{L}^{-1}, 30 \mathrm{ml}$ of soil extract $\mathrm{L}^{-1}$ and $5 \mathrm{ml} \cdot \mathrm{L}^{-1}$, of solution containing the following micronutrients: $\left(1 \mathrm{mg} \mathrm{ZnSO} \cdot 7 \mathrm{H}_{2} \mathrm{O}, 2 \mathrm{mg}\right.$ $\mathrm{MnSO}_{4} \cdot 4 \mathrm{H}_{2} \mathrm{O}, 10 \mathrm{mg} \mathrm{H}_{3} \mathrm{BO}_{3}, 1 \mathrm{mg} \mathrm{Co}\left(\mathrm{NO}_{3}\right) 2 \cdot 6 \mathrm{H}_{2} \mathrm{O}, 1 \mathrm{mg} \mathrm{MoO} \cdot 2 \mathrm{H}_{2} \mathrm{O}$, $0.005 \mathrm{mg} \mathrm{CuSO} \cdot 5 \mathrm{H}_{2} \mathrm{O}, 700 \mathrm{mg} \mathrm{FeSO} \cdot 7 \mathrm{H}_{2} \mathrm{O}$ and $800 \mathrm{mg}$ EDTA) $\cdot \mathrm{L}^{-1}$.

The photo-bioreactors were (3) circular reactors in series, of $2.10 \mathrm{~m}$ in diameter and $40 \mathrm{~cm}$ in height, which were set in a solar greenhouse. One of the bioreactors was heated and aerated. Each was operated independently in a batch mode and the biomass was harvested at least 5 days after the growth had reached the stationary phase. The procedure was to flocculate the cells and return the growth media into the reactors and continue the growth supplementing the growth media with more nutrients. The flocculated biomass was dried and subsequently was dried up in an oven with circulating air at $30^{\circ} \mathrm{C}$. Subsequently, the dried algal biomass was pulverized in a planetary ball mill at $350 \mathrm{rpm}$ for $15 \mathrm{~min}$. The pulverized biomass was weighed and the lipids were extracted with a mixture of hexane and isopropanol (in a ratio 3:2). To every $100 \mathrm{~g}$ of dried biomass, 500 $\mathrm{mL}$ of the solvent mixture was added. The extraction time was 6 hours at $25^{\circ} \mathrm{C}$. After filtration of the biomass the solvent was evaporated in order to obtain the lipids. The fatty acid content of the lipids was obtained by converting the lipids into their corresponding methyl esters by the process of transesterification and analyzing their profile with a gas chromatographer.

Analysis of biomass was also carried out in order to obtain the macronutrient content and ash content of the biomass. The macronutrients which were determined are: 1) total nitrogen (a measure of protein content), 2) starch, 3) lipids and 4) ENEO (refers to the remaining substances which are free of nitrogen and are not detected by the method used as they are lost in the solvent). Also the following were measured: 5) total fiber and 6) ash content. Total nitrogen and the lipid contents were determined via the Kjeldahl nitrogen and Soxhlet determination methods respectively. The carbohydrates in the dried algal biomass, with the exception of the starch, are lost during the process of extraction. The starch is converted into glucose with pancreatinase and subsequent hydrolysis with hydrochloric acid. The glucose is measured with the method of Luff-Schoort. The percentage of starch in the sample is equal to the percentage of glucose determined times the factor 0.72 . The ash content was determined by burning a pre-weighted sample first in a Bunsen burner and then in an oven at $575^{\circ} \mathrm{C}$.

The content in various metals such as $\mathrm{Na}, \mathrm{K}, \mathrm{Cu}, \mathrm{Zn}, \mathrm{Mn}, \mathrm{Fe}$, $\mathrm{Ca}, \mathrm{Mg}, \mathrm{Ni}, \mathrm{Pb}, \mathrm{Cr}$ and $\mathrm{Cd}$ was determined via combustion with 
acids $\left(10 \mathrm{~mL} \mathrm{HNO}_{3}+5 \mathrm{~mL} \mathrm{HCLO}_{4}\right)$, filtration and atomic absorption measurements of these metals in the filtrate. Total phosphorus was determined with the standard AGCD method.

\section{Results and discussion}

Three different sets of biomass samples were prepared for macronutrient analysis as follows: Set 1 (Sample 1 and Sample 2) was obtained after lipid extraction using ultrasound followed by limited drying naturally in air. Set 2 (Sample 1 and Sample 2) was obtained by drying biomass in the oven (complete moisture removal) at $40^{\circ} \mathrm{C}$ for several hours and, after pulverization of the sample at $300 \mathrm{rpm}$, extraction of the lipids with a mixture of isopropanol and hexane. Set 3 (Sample 1 and Sample 2) was dried in the oven also at $40^{\circ} \mathrm{C}$ for several hours but the lipids were removed. The macronutrient analysis of the three sets of samples is shown in Tables 1-3.

Table I Macronutrient content after removal of lipids with ultrasound and drying the samples naturally, without removing all the moisture

\begin{tabular}{lll}
\hline Type of Component & Sample I (\%) & Sample 2 (\%) \\
\hline Ash & 4.89 & 6.73 \\
Starch & 2.21 & 3.23 \\
Total nitrogen & 16.72 & 29.19 \\
Lipids & 0.51 & 3.52 \\
Moisture & 63.1 & 45.01 \\
Total fiber & 4.83 & 8.77 \\
\multicolumn{1}{c}{ ENEO* } & 7.74 & 3.55 \\
\hline
\end{tabular}

Table 2 Drying in oven and removal of lipids by pulverization and subsequent extraction

\begin{tabular}{lll}
\cline { 1 - 2 } Type of Component & Sample I (\%) & Sample 2 (\%) \\
\cline { 1 - 2 } Ash & 13.25 & 12.24 \\
Starch & 5.98 & 5.87 \\
Total Nitrogen & 45.3 & 53.08 \\
Lipids & 1.38 & 6.4 \\
Total Fiber & 13.09 & 15.95 \\
ENEO* & 21 & 6.46 \\
\hline
\end{tabular}

Table 3 Drying in an oven and pulverization without lipid removal

\begin{tabular}{lll}
\hline Type of Component & Sample I (\%) & Sample 2 (\%) \\
\hline Ash & 10.19 & 8.74 \\
Starch & 4.6 & 4.19 \\
Total Nitrogen & 34.85 & 37.91 \\
Lipids & 24.14 & 33.16 \\
Total Fiber & 10.07 & 11.39 \\
ENEO* & 16.15 & 4.61 \\
\hline
\end{tabular}

Total ENEO (Free of Nitrogen Extractable Substances) are considered as carbohydrates
Therefore the total carbohydrate content is about $20.77 \%$ for sample 1 and about $8.8 \%$ for sample 2 . By observing Tables $1-3$, it is evident that no complete lipid removal is possible either with the use of ultrasound or with extraction. The total nitrogen reflects the percentage composition of the dry biomass in proteins. Because about $5-12 \%$ of the total nitrogen found in algae occurs in the cell membranes, in Table 3 the protein content in sample 1 should vary between $31.3 \%$ and $33 \%$ while in sample 2 it should vary between $34.1 \%$ and $36 \%$. It appears that the Chlorella vulgaris biomass is rich in protein and therefore it potentially can be used as a supplement in animal feed. Also, the lipid content is of great importance as, from an analysis of the fatty acid distribution it contains about $18-19 \% \omega-3$ in the form of $\alpha$-linolenic acid.

Other nutrients obtained in the biomass are various antioxidant micronutrients. These have been measured as total phenolic compounds. Their presence is a measure of the antioxidant capacity of the biomass. The analysis performed measured the total amount of phenols as the equivalent of Gallic acid (GAE).$^{29}$ This was found equal to $6000 \mu \mathrm{g}(\mathrm{GAE}) \mathrm{g}^{-1}$ air dried biomass. As a comparison the values in red wine and dried oregano are $3000 \mathrm{mg}(\mathrm{GAE}) \mathrm{L}^{-1}$ and $66 \mathrm{mg}$ (GAE) $\mathrm{g}^{-1}$ respectively. ${ }^{30,31}$ By using the FRAP method the antioxidant capacity was measured equal to $43.1 \mu$ mols FRAPg ${ }^{-1}{ }^{31}$ It therefore appears that the micronutrient content of Chlorella vulgaris biomass is significant. The high content of the biomass in $\omega-3$ lipids as well as its high antioxidant potential may be responsible for the strengthening of the immune system observed in fish when they were fed food supplemented with algal meal. ${ }^{19-22}$

Table 4 shows the variation in lipid content as well as the biomass production of Chlorella vulgaris as the initial nitrogen content in the growth media is varied. The cultivation was performed in a batch mode and was terminated 5 days after the stationary phase was achieved.

Table 4 Total production of biomass (dry) of Chlorella vulgaris obtained per $50 \mathrm{~L}$ growth media and lipid content of the dry biomass

\begin{tabular}{lll}
\hline $\begin{array}{l}\text { Initial nitrogen } \\
\text { concentration }\end{array}$ & $\begin{array}{l}\text { Production of } \\
\text { Chlorella vulgaris }(\mathbf{g})\end{array}$ & $\begin{array}{l}\text { Lipid content } \\
(\%) \text { w/w. }\end{array}$ \\
\hline $\mathrm{N}=$ trace & $5.88 \mathrm{~g}$ & $42 \%$ \\
$\mathrm{~N}=122.65 \mathrm{mg} / \mathrm{L}$ & $15.91 \mathrm{~g}$ & $32 \%$ \\
$\mathrm{~N}=590.15 \mathrm{mg} / \mathrm{L}$ & $16.86 \mathrm{~g}$ & $25 \%$ \\
$\mathrm{~N}=1057.65 \mathrm{mg} / \mathrm{L}$ & $13.80 \mathrm{~g}$ & $7 \%$ \\
\hline
\end{tabular}

A maximum lipid content of $42 \%$ was measured. However, in the case where higher percentages of lipids are wanted, this percentage can be increased significantly if the cultivation is continued well past the stationary phase and the reactor operated in a semi-batch mode by adding $\mathrm{K}, \mathrm{P}$ and very small amounts of $\mathrm{N}$. In general, as the percentage of lipids is increased the percentage of proteins is decreased and vice versa. From Table 4 it appears that biomass productivity is affected by low or very high amounts of nitrogen. Lipid productivity is given by the following equation (Eq. 1):

$$
\mathrm{PL}=\mathrm{PM}_{\mathrm{X}} \mathrm{LC}
$$

Where, PL and PM are the lipid and biomass productivities and LC is the lipid content of the biomass. 
It becomes evident that in order to maximize biomass productivity it is important to work with a specific nitrogen concentration depending on which species one works with. ${ }^{33}$ However, the lipid content is also highly dependent on the macronutrient concentration in the growth media and in general terms it increases as nitrogen is restricted in the growth media. ${ }^{34}$ Therefore, in order to maximize lipid productivity one has to maximize the lipid content while keeping biomass productivity nearly the maximum level. This, in continuous cultures will require starting up with a medium to relatively high nitrogen concentration in order to achieve high growth rates and, after the stationary phase has been achieved, it will require intermittent feeding of the bioreactor with nitrogen and other macronutrients along the length of the bioreactor in order to simulate the semi-batch mode and keep low the nitrogen concentration.

Table 5 shows the composition of the biomass of the algae Chlorella vulgaris in metals and phosphorus, while Table 6 shows an indicative composition of the lipids of Chlorella vulgaris in eight fatty acids occurring in highest proportions.

Table 5 Composition of Chlorella vulgaris in trace elements and phosphorus

\begin{tabular}{lc}
\hline Composition of Chlorella Vulgaris \\
\hline Zn-Total $(\mathrm{mg} / \mathrm{kg})$ & 213.2 \\
Mn-Total $(\mathrm{mg} / \mathrm{kg})$ & 6.37 \\
Mg-Total $(\mathrm{mg} / \mathrm{kg})$ & 96.2 \\
Cu-Total $(\mathrm{mg} / \mathrm{kg})$ & 54.4 \\
Na-Total $(\mathrm{g} / \mathrm{kg})$ & 2.1 \\
K-Total $(\mathrm{g} / \mathrm{kg})$ & 5.7 \\
Fe-Total $(\mathrm{g} / \mathrm{kg})$ & 4.99 \\
P-Total $(\%)$ & 0.67 \\
\hline
\end{tabular}

As can it be seen from Table 5, the Chlorella vulgaris biomass is rich in important trace minerals, which are deemed important not only for animal nutrition but also potentially for human nutrition. No heavy metals such as $\mathrm{Cd}, \mathrm{Ni}$ and As were detected. From Table 6 the concentration in $\alpha$-linolenic acid is about $19 \%$ while, the concentration of linoleic acid $(\omega-6)$ is very high about $43 \%$.

Table 6 Composition of Chlorella vulgaris in fatty acids

\begin{tabular}{lll}
\hline Fatty acid & Name & $\begin{array}{l}\text { Percentage in the } \\
\text { lipids }(\% \mathrm{w} / \mathbf{w})\end{array}$ \\
\hline CI4:0 & mirisitic acid & 0.454 \\
CI6:0 & palmitic acid & 15.878 \\
CI6:I & Palmitoleic acid & 0.426 \\
CI8:0 & stearic acid & 2.815 \\
CI8:1 & oleic acid & 17.778 \\
CI8:2 & linoleic acid & 43.18 \\
C18:3 & linolenic acid & 18.45 \\
C20:0 & arachidic cid & 0.223 \\
\hline
\end{tabular}

\section{Conclusion}

The biomass of microalgae Chlorella vulgaris contains a complete array of macro and micro nutrients constituting it a potentially good source in animal feed and in human nutrition. By altering the macronutrient concentration in the growth media, the relative percentage of proteins and lipids can be manipulated in order to obtain biomass with the macronutrient proportions ideally suited for each occasion. Furthermore, algal species from a very large array of species can be grown.

In Chlorella vulgaris, a protein content as high as $53 \% \mathrm{w} / \mathrm{w}$ can be obtained. In addition, the protein amino acid composition favorably compares with that of soy and egg. The lipids contain relatively high percentage of $\alpha$-linolenic acid. The biomass of Chlorella vulgaris also contains many important minerals and has a high antioxidant capacity, about $50 \%$ higher than that of red wine.

\section{Acknowledgement}

This research has beenco-financedby the EuropeanUnion(European Social Fund-ESF) and Greek national funds through the Operational Programs "Competitiveness and Entrepreneurship and Regions in Transition" of the National Strategic Reference Framework (NSRF)Research Funding Program: COOPERATION-11SYN_07_472 (Scientific Coordinator: Prof. George Papapolymerou).

\section{Conflict of interest}

The author declares that there in none of the conflicts.

\section{References}

1. Dianursanti M, Nasikin, Wijanarko A. Development of discontinous filtration system for enhancing biomass production and $\mathrm{CO}_{2}$ fixation from chlorella vulgaris buitenzorg. Inter J Algae. 2012;14(4):357-366.

2. Ergasheva HE. Seasonal changes in species composition of algae of the andijan reservoir (the Republic of Uzbekistan). Inter $J$ Algae. 2017;19(2):111-118

3. Falter C, Voigt CA. Improving biomass production and saccharification in Brachypodium distachyon through overexpression of a sucrosephosphate synthase from sugarcane. Journal of Plant Biochemistry and Biotechnology. 2016;25(3):311-318.

4. Gautam K, Pareek A, Sharma DK. Exploiting microalgae and macroalgae for production of biofuels and biosequestration of carbon dioxide- A review. International Journal of Green Energy. 2015;12(11):1122-1143.

5. Malik VS. Editorial biofuel: The butanol perspective and algal biofuel. Journal of Plant Biochemistry and Biotechnology. 2014;23(4):337-338.

6. Carrillo-Reyes J, Barragán-Trinidad M, Buitrón G. Biological pretreatments of microalgal biomass for gaseous biofuel production and the potential use of rumen microorganisms: A review. Algal Research. 2016;(18):341-351.

7. Chakradhar M, Upreti M, Tuli DK, et al. Micro-algae: Biofuel Production and $\mathrm{CO}_{2}$ Sequestration Concept, Prospects and Challenges. Journal of the Petrotech Society. 2008;5(3):23-29.

8. Lardon L, Hélias A, Sialve B, et al. Life-Cycle Assessment of Biodiesel Production from Microalgae. Environ Sci Technol. 2009;43(17):6475-6481.

9. Singh J, Gu S. Commercialization potential of microalgae for biofuels production. Renewable and Sustainable Energy Reviews. 2010;14(9):2596-2610.

10. Zhu L. Microalgal culture strategies for biofuel production: A review. Biofuels, Bioproducts and Biorefining. 2015;9(6):801-814.

11. Hempel F, Bozarth AS, Lindenkamp N, et al. Microalgae as bioreactors for bioplastic production. Microb Cell Fact. 2011;10:81. 
12. Panagiotidou E, Konidaris C, Baklavaridis A, et al. A simple route for purifying extracellular poly(3-hydroxybutyrate)-depolymerase from penicillium pinophilum. Enzyme Res. 2014:159809.

13. Borowitzka MA. Vitamins and fine chemicals from micro-algae. In Borowitzka MA, Borowitzka LJ, editors. Micro-algal biotechnology. Cambridge University Press, Cambridge; 1988:153-196.

14. Lorenz RT, Cysewski GR. Commercial potential for Haematococcus microalgae as a natural source of astaxanthin. Trends Biotechnol.2000;18(4):160-167.

15. Waldenstedt L, Inborr J, Hansson I, et al. Effects of astaxanthinrich algal meal (Haematococcus pluvalis) on growth performance, caecal campylobacter and clostridial counts and tissue astaxanthin concentration of broiler chickens. Animal Feed Science and Technology. 2003;108(1-4):119-132.

16. Becker W Microalgae in human and animal nutrition. In: Richmond A, editor. Handbook of Microalgal Culture: Biotechnology and Applied Phycology. Blackwell, Oxford; 2004:312-351.

17. Becker EW. Micro-algae for human and animal consumption. In: Borowitzka MA, Borowitzka LJ, editors. Micro-algal biotechnology. Cambridge University Press, Cambridge; 1988:222-256.

18. Brown MR, Jeffrey SW, Volkman JK, et al. Nutritional properties of microalgae for mariculture. Aquaculture. 1997;151(1-4):315-331.

19. James CM, Hinty SA, Salman AE. Growth and $\omega-3$ fatty acid and aminoacid composition of microalgae under different temperature regimes. Aquaculture. 1989;77(4):337-351.

20. Ju ZY, Deng DF, Dominy W. A defatted microalgae (Haematococcus pluvialis) meal as a protein ingredient to partially replace fishmeal in diets of Pacific white shrimp (Litopenaeus vannamei). Aquaculture. 2012;354355:50-55.

21. Kreeger DA, Langdon CJ. Effect of dietary protein content on the growth of juvenile mussels, Mytilus trossulus. Biol Bull. 1993;185(1):123-139.

22. Nagel F, Slawski H, Adem H, et al. Albumin and globulin rapeseed protein fractions as fishmeal alternative in diets fed to rainbow trout (Oncorhynchus mykiss W.). Aquaculture. 2012;354-355:121-127.

23. Lin Q, Lin J (2011) Effects of nitrogen source and concentration on biomass and oil production of a Scenedesmus rubescens like microalga. Bioresour Technol. 2011; 102(2):1615-1621.
24. Solovchenko AE, Khozin-Goldberg I, Didi-Cohen S, et al. Effects of light intensity and nitrogen starvation on growth, total fatty acids and arachidonic acid in the green microalga Parietochloris incise. $J$ Appl Phycol. 2008;20:245-251.

25. Chen M, Tang H, Ma H, et al. Effect of nutrients on growth and lipid accumulation in the green algae Dunaliella tertiolecta. Bioresour Technol. 2011;102(2):1649-1655.

26. Richmond A. Principles for attaining maximal microalgal productivity in photobioreactors: An overview. Hydrobiologia. 2004;512(1-3):33-37.

27. Yoo C, Jun SY, Lee JY, et al. Selection of microalgae for lipid production under high levels carbon dioxide. Bioresour Technol. 2010;101(Supp1 1):S71-S74.

28. Andersen RA, Jacobson DM, Sexton JP, et al. Center for Culture of Marine Phytoplankton. Catalogue of Strains. West Boothbay Harbor, Maine, USA; 1991.98 p.

29. Singleton VL, Rossi SA. Colorimetry of Total Phenolics with Phosphomolibdic-phosphotungestic Acid Reagents. Am J Enol Vitic. 1965;16:144-158.

30. Gougoulias N. Study on polyphenols content and antioxidative activity of oregano (Origanum vulgare L.) of different origin. Oxidation Communications. 2009;32(4):917-923.

31. Gougoulias N. Study on polyphenol content and antioxidant activity of selected wines from the island of Crete, Greece. Oxidation Communications. 2010;33(2):443-451.

32. Benzie IF, Strain JJ. Ferric reducing/antioxidant power assay: direct measure of total antioxidant activity of biological fluids and modified version for simultaneous measurement of total antioxidant power and ascorbic acid concentration. Methods Enzymol. 1999;299:15-27.

33. Papapolymerou G, Gougoulias N, Spiliotis X, et al. Effect of different concentrations of macronutrients on the growt rate and cultivation of Algae specie Chlorella vulgaris. Annals of the University of Craiova, Series Biology and Environmental Engineering. 2014;19(LV):557-562.

34. Becker EW. Micro-algae as a source of protein. Biotechnology Advances. 2007;25:207-210. 